\title{
Comparative Growth and Survival of Juvenile Atlantic Cod (Gadus morhua) Cultured in Copper and Nylon Net Pens
}

\author{
Michael Chambers ${ }^{1 *}$, Jon Bunker ${ }^{2}$, Win Watson III $^{2}$ and Howell WH$^{2}$ \\ ${ }^{1}$ Jere A Chase Ocean Engineering Lab, University of New Hampshire, 25 Colovos Road, Durham, NH 03824, USA \\ ${ }^{2}$ Department of Biological Sciences, University of New Hampshire, Durham, NH 03824, USA
}

\begin{abstract}
Bio-fouling on net pens has been a major concern for the marine aquaculture industry. As cage systems increase in size, so does the surface area for the attachment of colonial organisms that create drag on the net, reduce water flow important to fish health, and increase operational expenses due to net cleaning. To solve this problem, the International Copper Association (ICA) has been developing copper alloy netting for sea cages. Copper netting has unique properties that minimize bio-fouling, reduce the risk of fish escapement, prevent predators from entering the net pen, and is recyclable. To test the alloy netting, an experiment was conducted to compare juvenile cod cultured in traditional nylon nets with cod grown in Seawire copper netting (Seawire@Luvata.com). Six, 0.78 m $^{3}$ cages were each stocked with 200 Atlantic cod (Gadus morhua) averaging $29 \pm 2.2 \mathrm{~g}$ and grown for 4 months in coastal waters of New Hampshire, USA. Results of the study indicated no significant differences in cod growth, survival, feed conversion ratio (FCR), specific growth rate (SGR), or Fulton's condition factor (K) between the fish grown in the copper alloy and nylon nets. A chemical analysis was conducted on the cod and indicated no differences in copper levels in muscle, liver and gill tissues taken from the net treatments. Nylon nets with antifouling paint accumulated significantly more bio-fouling than the copper nets. Materials that were in direct contact with the copper netting (plastic cable ties) fouled heavily with hydroids indicating minimal leaching to the environment. This study describes some of the beneficial attributes of copper netting, however future studies need to be conducted over a longer period of time, on a larger scale, and in a more energetic environment to definitively test the utility of this new product.
\end{abstract}

Keywords: Cage culture; Biofouling; New containment materials; Atlantic cod; Gadus morhua; Fish health

\section{Introduction}

The marine aquaculture industry is moving towards more environmentally sustainable practices. A common issue with cage farming is the attachment of biological communities to the culture net creating reduced water flow, decreased water quality and excessive weight and drag on the cage floats [1-6]. Aquaculture nets are prone to settlement and successional development of hydroids [7] that significantly increase operational costs of farming due to net cleaning [8-10]. To combat this problem, the industry impregnates their nets with antifouling paints with active ingredients such as cuprous oxide, cadmium and zinc [814]. The active ingredients eventually leach out over time (10-12 months) and thus fouling organism adheres to the net surface [9].

A new approach to circumvent this problem has been the development of new containment materials that are stronger, resistant to bio-fouling and friendly to the environment. The International Copper Association (ICA) has been investigating copper alloy netting for fish farming [15]. Copper netting exhibits both antifouling and anticorrosion properties. When copper netting is introduced into seawater, an adherent protective patina layer is formed, that inhibits corrosion and resists the attachment of fouling organisms. A clean net maintains water movement through the cage for optimal fish health. Moreover, net cleaning is expensive, time consuming and stressful to the fish. The strength of copper netting helps prevent escapement and deters predators such as seals and sharks. Lastly, at the end of the copper netting shelf life, it can be sold back to the manufacturer and recycled into another copper net or product.

Copper is naturally occurring in water, sediments and organisms, and is an essential micronutrient for normal growth in plants and animals [16]. As such, fish diets for aquaculture maintain copper levels ranging from $5-14.8 \mathrm{mg} / \mathrm{kg}$ [17]. Copper is also used as a biocide to treat fish disease including ectocommensal ciliates [18], Amyloodinium
[19], Cryptocaryon [20] and Monogenes [21]. Despite these positive attributes, it should be noted that fish are much more sensitive to aqueous metals than humans, and too much copper can cause metal poisoning. Copper toxicosis affects the gills, resulting in osmoregulatory dysfunction, and can affect the kidney and liver [22]. Therefore, oxidation levels from copper netting must be minimal for fish to remain healthy.

Atlantic cod is one of the most valuable and commonly consumed species in the western world, and declines of wild populations have brought a renewed interest in cod aquaculture. In New England, research efforts have been underway at the University of Hampshire's (UNH), Open Ocean Aquaculture (OOA) site (http://ooa.unh.edu/) to develop grow out technologies for this species [23-26]. Recent developments in cod larval production in the US, Norway, Canada and the UK have created a consistent supply of fingerlings for grow out in cages. Despite successes in hatchery production, culture issues remain with ocean nursery and grow out systems. One behavioral issue with cod is their tendency to bite at the net twine creating holes through which the fish can escape [27]. This has been a problem in Norway that has slowed the expansion of the industry. It is clear that alternative containment materials that reduce bio-fouling and escapement would be beneficial to the industry.

The goal of this research was to compare the growth, survival and

*Corresponding author: Michael Chambers, Jere A Chase Ocean Engineering Lab, University of New Hampshire, USA, Tel: +1 603-862-3394; Fax: +1 603-862-0241; Email: Michael.Chambers@unh.edu

Received March 21, 2012; Accepted June 25, 2012; Published June 30, 2012

Citation: Chambers M, Bunker J, Watson III W, Howell WH (2012) Comparative Growth and Survival of Juvenile Atlantic Cod (Gadus morhua) Cultured in Coppe and Nylon Net Pens. J Aquacult Res Dev 3:137 doi:10.4172/2155-9546.1000137

Copyright: (c) 2012 Chambers, et al. This is an open-access article distributed under the terms of the Creative Commons Attribution License, which permits unrestricted use, distribution, and reproduction in any medium, provided the original author and source are credited. 
behavior of juvenile Atlantic cod cultured in copper alloy and traditional, industry standard nylon net pens with antifouling paint. It also compared fouling rates on the two net types, and examined $\mathrm{Cu}$ levels that may have been absorbed into the fish from the copper netting. The four month experiment was conducted at the UNH Marine Pier Facility in New Castle, NH, USA during the spring and summer of 2010.

\section{Methods and Materials}

\section{Cage design}

A total of six floating cages were constructed, each with a volume of $0.78 \mathrm{~m}^{3}$. These were attached to a wooden raft located near the UNH pier in Newcastle, NH, USA. Each cage frame was made from $2.5 \mathrm{~cm}$ diameter high density polyethylene pipe (HDPE). Netting materials were stretched and cable tied to each frame. The three nylon cages (control) were made from $1.25 \mathrm{~cm}$ x $1.25 \mathrm{~cm}$ mesh nylon coated with Flexgard $^{\text {sw }}$, a cuprous oxide based antifouling paint (http://www.trademarkia.com/company-flexabar-corporation-451575-page-1-2, New Jersey, USA). Flexgard is the industry standard antifoul paint used for salmon aquaculture in the eastern US and Canada. The three copper cages (treatment) utilized Seawire ${ }^{\mathrm{T \omega}}$, a copper silicone material produced by Luvata (Seawire@Luvata.com. Appleton, WI USA). At the time of the experiment, Luvata only produced a $2.5 \mathrm{~cm} \times 2.5 \mathrm{~cm}$ mesh net. To match the copper net to the nylon mesh size of $1.25 \mathrm{~cm}$ (the size necessary to maintain small cod in the cage), two pieces of Seawire net were laid on top of each other and spaced to form a $1.25 \mathrm{~cm} \mathrm{x} 1.25 \mathrm{~cm}$ mesh. Cable ties and copper hog rings were used to secure the Seawire in place and keep it from shifting into a larger mesh size.

\section{Stocking and feed}

Each cage was stocked at a density of $7.4 \mathrm{~kg} / \mathrm{m}^{3}$ with $200,29 \pm 2.2$ g cod produced by Great Bay Aquaculture located in Newington, $\mathrm{NH}$ USA. Initially, the cod were fed twice daily with a vibratory feeder at $1.5 \%$ body weight/day with a $3 \mathrm{~mm}$, Skretting ${ }^{\mathrm{Tm}}$ Europa diet composed of $50 \%$ protein and $18 \%$ lipid (Portland, ME USA). Later in the experiment, cod were hand fed to satiation, once daily.

\section{Behavioral and environmental monitoring}

Each cage was monitored with a Super Circuits ultra-high resolution camera (Model \# PC88WR-2, Austin, TX USA) and video was recorded on a Super Circuits 8 channel DVR (Model \# DH200800D, Super Circuits, Austin, TX USA). Feeding, swimming behavior and interactions with the nets were recorded on the DVR. Water temperature, dissolved oxygen, salinity, $\mathrm{pH}$, turbidity and tidal height were recorded every 30 minutes with an YSI 6600 Multi-parameter Sonde (YSI, Yellow Springs, Ohio USA). Light levels were monitored from the bottom of the cages with a HOBO Pendant Temperature and Light Data Logger ( Onset Computer Corp, Cape Cod, MA USA), and current speed and direction were measured periodically with a portable Marsh McBirney, model 2000, flow meter (Hach Company, Berlin, MA USA).

\section{Data collection}

Random samples of 30 cod were collected monthly from each cage to measure wet weight and total length. Fish were starved for 24 hrs prior to sampling. At the termination of the study (4 months), FCRs, based on 50 fish from each of the control and copper nets, were calculated as [total feed weight fed * \% dry matter] / [(mean harvest weightinitial mean weight) ${ }^{*}$ number of fish].

Standard indices of growth and condition of fish were calculated for each cage. SGR $\left(\%\right.$ day $\left.^{-1}\right)$ was calculated as $\left[\left(\ln \left(\mathrm{W}_{2}\right)-\ln \left(\mathrm{W}_{1}\right)\right] /\left(\mathrm{t}_{2}-\right.\right.$ $t_{1}$ ) where $W_{2}$ and $W_{1}$ are the mean live body weights at times $t_{2}$ and $t_{1}$, respectively. Fulton's condition factor was calculated with the formula $\mathrm{K}=\left(\mathrm{W} / \mathrm{L}^{3}\right) \times 100$, where $\mathrm{W}$ is the wet weight $(\mathrm{g})$, and $\mathrm{L}$ is the total length $(\mathrm{cm})$.

Chemical analyses of 3 replicate tissue samples of gill, liver and muscle, each weighing 5-10g and taken from 10 randomly selected fish from the copper alloy and nylon nets, were run at the end of the experiment. Tissue samples were frozen in zip lock bags and shipped to New Jersey Feed Labs in Trenton, NJ, USA. There, samples were placed into a crucible and heated to $600^{\circ} \mathrm{C}$ for $2 \mathrm{hrs}$. The dry ash sample was then diluted with hydrochloric acid and placed into an IC-AES (Inductively Coupled Plasma Atomic Emission Spectrometry) to measure copper content (AOAC \# 985.01)

Finally, each cage with fouling community was removed from the water and weighed on an Ohaus ES series bench scale (Parsippany, NJ USA) for total weight. Fouling organisms were identified and photographed. Each cage was then pressure sprayed clean and re-weighed to obtain weight differences between fouled and clean cages.

Unpaired t-tests were used to compare survival, FCR, SGR, K, copper uptake and biofouling results between the control and treatment nets.

\section{Results}

\section{Environmental}

Environmental data collected during the study showed: a) current was omnidirectional, and varied from $0.2-0.4 \mathrm{~cm} / \mathrm{sec}$; b) water temperature ranged from $6.4^{\circ} \mathrm{C}$ in April to $19.2^{\circ} \mathrm{C}$ in August; c) light levels in the bottom of net cages $(\sim 1.5 \mathrm{~m})$ ranged from $0-2$ lumens/ $\left./ \mathrm{ft}^{2} ; \mathrm{d}\right)$ salinity ranged from 21.5 - $34.3 \mathrm{ppt}$; and e) dissolved oxygen ranged from 11.3 $\mathrm{mg} / \mathrm{l}$ in April to $6.3 \mathrm{mg} / \mathrm{l}$ in August.

\section{Cod performance}

Fish increased in weight by $80.8 \pm 2.2 \mathrm{~g}$ in the nylon cage and 84.9 $\pm 9.4 \mathrm{~g}$ in the Cu cage during the 16 week trial (Figure 1 and Table 1). Mean weights from replicates in each treatment were not significantly different (Kruskal-Wallis tests, $\mathrm{P}>0.05$ ) so all replicate weights within treatment were combined. There was no significant difference in mean weight (Unpaired t-test with Welch correction, $\mathrm{P}>0.05$ ) between fish raised in the copper alloy and Flexgard treated nylon cages. Also not significantly different (Unpaired t-tests, $\mathrm{P}>0.05$ ) were cod lengths, survival, FCR, SGR and K (Table 1).

In mid-May, three consecutive storms and runoff increased water turbidity in the Piscataqua River. Shortly after this event, mortality was observed in all of the cages. Cod postmortem samples (6/cage) were submitted for necropsy at the UNH Veterinary Diagnostic Laboratory

\begin{tabular}{|l|l|l|}
\hline & Nylon cage & Copper cage \\
\hline Initial weight $(\mathrm{g})$ & $29.2 \pm 6.7$ & $29.2 \pm 6.7$ \\
\hline Final weight $(\mathrm{g})$ & $110.0 \pm 1.25$ & $114.1 \pm 2.28$ \\
\hline Weight gain $(\mathrm{g})$ & $80.8 \pm 0.3$ & $84.9 \pm 1.3$ \\
\hline Initial length $(\mathrm{cm})$ & $15.4 \pm 1.0$ & $15.4 \pm 1.0$ \\
\hline Final length $(\mathrm{cm})$ & $22.2 \pm 0.01$ & $22.3 \pm 0.11$ \\
\hline Length gain $(\mathrm{cm})$ & $6.8 \pm 0.02$ & $6.9 \pm 0.05$ \\
\hline Survival $(\%)$ & $29.17 \pm 1.20$ & $27.67 \pm 2.41$ \\
\hline FCR & $1.52 \pm 0.45$ & $1.51 \pm 0.13$ \\
\hline SGR (\%/day) & $0.72 \pm 0.07$ & $0.75 \pm 0.07$ \\
\hline Condition factor $(\mathrm{K})$ & 1 & 1 \\
\hline
\end{tabular}

Table 1: Growth performance of cod in nylon and copper cages. Means are \pm SE Unpaired T-tests showed no significant differences $(P>0.05)$ in any of the measured variables between cage types. 


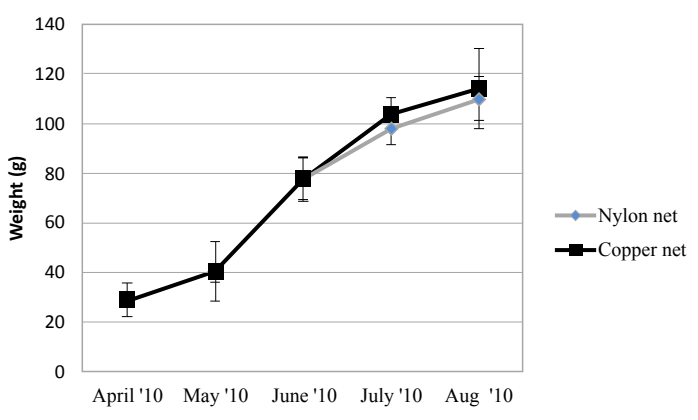

Figure 1: Mean weight gain $( \pm S E)$ of Atlantic cod cultured in nylon and copper nets. Mean weights from replicates in each treatment were not significantly different (Kruskal-Wallis tests, $\mathrm{P}>0.05$ ) so all replicate weights within treatment were combined. There was no significant difference in mean weight (Unpaired t-test with Welch correction, $\mathrm{P}>0.05$ ) between fish raised in the copper alloy and Flexgard ${ }^{\mathrm{TM}}$ treated nylon cages.

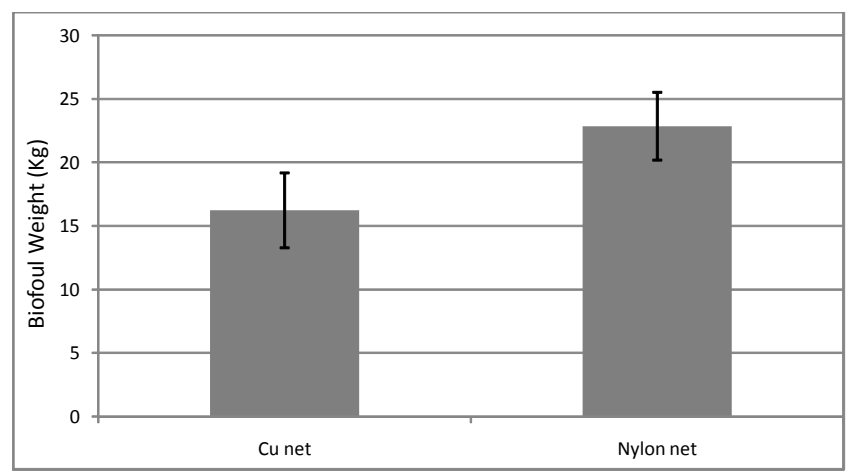

Figure 2: Mean total bio-foul weight $( \pm \mathrm{SE})$ from each cage at the termination of the experiment. Bio-foul weight on the copper pens was significantly less $(16.2 \pm 1.70 \mathrm{~kg})$ than the bio-foul weight on the nylon pens $(22.8 \pm 1.54 \mathrm{~kg})$ (Unpaired T-test, $\mathrm{P}<0.05$ )

in Durham, NH. The cod were diagnosed with Aeromonas salmoncida septicemia, with focally marked fibrinonecrotizing dermatitis of the dorsal fin. Consequently, slow chronic mortality was observed during the rest of the experiment despite increased growth rates in all the cages.

\section{Biofouling}

As temperatures increased through the summer (up to $19^{\circ} \mathrm{C}$ ), so did the amount of bio-fouling on the HDPE frames and nylon nets. Organisms found on the two cage treatments included the hydroid Tubularia crocea, the red gilled nudibranch (Coryphella sp.), skeleton shrimp (Caprella sp.) and the tunicate Ciona intestinalis. Tubularia was the dominant fouling species that reduced water flow through the cages. Bio-fouling rates between the treated nylon net and copper netting were significantly different $(\mathrm{T}$-test, $\mathrm{P}<0.05)$. The mean $( \pm \mathrm{SE})$ fouling weight (fouling community alone) of the nylon nets was $22.8 \pm 2.67$ $\mathrm{kg}$ compared to a mean weight of $16.2 \pm 2.95 \mathrm{~kg}$ for the copper net pens (Figure 2). Fouling on the $\mathrm{Cu}$ cages only occurred on non-alloy materials (HDPE frame and plastic cable ties). The $2 \times 3 \mathrm{~mm}$ cable ties wrapped around the $\mathrm{Cu}$ twine had clumps of Tubularia ranging from 125-180g. No fouling organisms were observed on the Seawire netting.

\section{Copper content analysis}

Unpaired t-tests, with Welch corrections, were used to compare fish from copper alloy cages (treatment) and the fish from the nylon Flexgard cages (control). There was no significant difference $(\mathrm{P}>0.05)$ in ppm copper between fish from the 2 cage types in bodies (muscle) $(\mathrm{P}=0.68)$, gills $(\mathrm{P}=0.47)$ or livers $(\mathrm{P}=0.52)$ (Figure 3$)$.

\section{Discussion}

Nylon nets covered with antifouling paint $\left(\right.$ Flexgard $\left.^{\mathrm{m}}\right)$ are commonly used to prevent antifouling on aquaculture nets in North America. The disadvantages of these nylon nets include wear, vulnerability to predators, susceptibility to cultured species with biting behavior (e.g. cod), and bio-fouling once the antifouling coating is lost. Copper alloy netting provides a new containment material that may resolve some of these issues. Its strength, corrosion resistance, and antifouling properties provide longer wear, help to maintain water flow, prevent escapement and exclude predators. Furthermore, because of the reduced fouling communities and increased water flow, smaller mesh copper nets could be used to hold juvenile fish. This would allow fingerling fish to be moved to net pens at smaller sizes, thus reducing operating expenses associated with land based hatcheries.

We found no significant differences in the growth, survival, FCR SGR, and $\mathrm{K}$ between cod cultured in the nylon nets with Flexgard antifoul paint and cod raised in the copper nets. Despite the mortality caused by the bacteria infection Aeromonas salmoncida, the survival of the fish in the control and treatment was similar. Moreover, there were no difference in copper uptake in gill, liver and muscle tissue samples taken from fish held in nylon cages with Flexgard ${ }^{\text {Tw }}$ antifoul paint (cuprous oxide based) and the copper Seawire cages. Therefore, even though copper can be detrimental to fish, these data indicate that the copper cages used for this experiment had no obvious negative impact on fish growth or survival. Other findings were that nylon nets with antifouling paint accumulated significantly more fouling biomass than the copper alloy nets, and that the most abundant fouling organism, found on all cage frames, and on the twine of the nylon nets, was the hydroid Tubularia crocea. Hydroids are common, and quickly settle onto substrates before other species establish themselves [28-30]. This species grew throughout the experiment, but remained absent on all of the Seawire net material. The patina layer that forms on the Seawire net helps prevent hydroid stolons from attaching. Hydroids use different attachments methods on nylon nets that include growth between and around individual netting fibers [3].

Cable ties that were used to secure the two layers of copper netting together did foul with Tubularia. Hydroid colonies up to $180 \mathrm{~g}$ in weight were found on $2 \times 3 \mathrm{~mm}$ plastic ties that were in direct contact

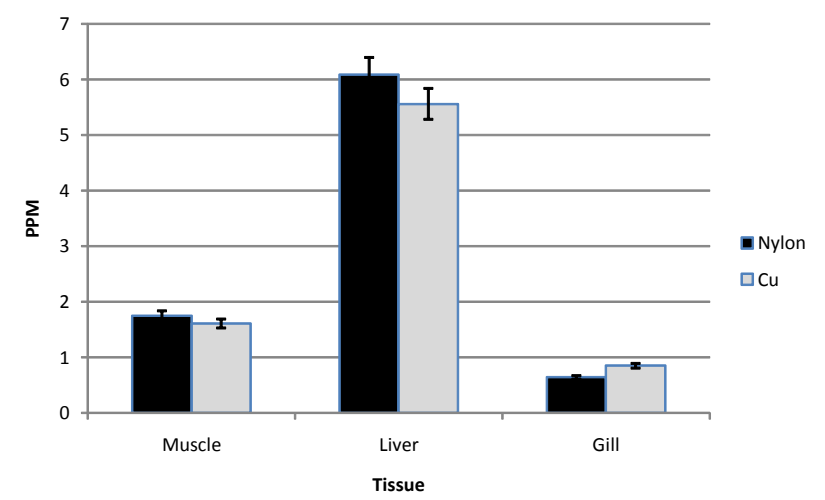

Figure 3: Chemical analysis conducted on cod muscle, liver and gill from the control, (nylon nets with Flexgard ${ }^{\mathrm{TM}}$ paint) and the treatment (copper Seawire pens). Unpaired t-tests, with Welch corrections, were used to compare the two, and there was no significant difference $(P>0.05)$ in ppm copper between fish from the 2 cage types in muscle $(P=0.68)$, gills $(P=0.47)$ or livers $(P=0.52)$. 
with the Seawire net. The significant fouling growth on the cable tie, in direct contact with the Seawire, suggests localized copper release. It also indicates that all fasteners used in copper alloy cage construction should be made of similar copper fasteners to eliminate fouling.

Although this study found no adverse affects of copper alloy netting on cod, future investigations should include longer term, commercial scale trials of copper alloy netting. Inquiries should be conducted with marine fish species in cold, temperate and tropical environments with different fouling communities. Other areas to research include copper leaching into the environment over time and its effect on benthic communities near the fish farm. Results of such studies will help determine copper netting shelf life, corrosion strength, benefits to aquaculture and effects on the marine environment. The data will also serve to guide the design and manufacture of future alloy nets for aquaculture.

\section{Conclusion}

Biofouling is a major concern with cage farming throughout the world. At present, the salmon farming industry uses nylon nets treated with an antifoul paint to reduce biofouling. Seawire represents a new material that could deter biofouling while minimizing escapement and preventing most predators from entering the cage environment. Unlike nylon nets that are disposed of when worn out, Seawire maintains its value and can be recycled. The cost of $2 \mathrm{~cm}$ mesh nylon net, treated with Flexgard is $\$ 16.87 / \mathrm{m}^{2}$ compared to Seawire with $2.4 \mathrm{~cm}$ mesh is $\$ 39.69 /$ $\mathrm{m} 2$. Despite the initial cost difference, Seawire may be as cost effective as nylon by decreasing operational costs associated with net cleaning, repair and rotation.

Seawire netting comes in roles $1.25 \mathrm{~m}$ x $31.25 \mathrm{~m}$. Cages can be easily manufactured to different dimensions with a pneumatic cutter and stapler. Seawire is a welded copper mesh that maintains a rigid geometry even during high current episodes when nylon nets can compress and loose volume. The rigidity may cause challenges in the fabrication and deployment of commercial size cages. These operational methods and expenses will need to be calculated to fully understand the cost benefits of using the wire in an ocean environment.

Copper alloy netting has been investigated in larger scale systems in Tasmania, Japan and more recently in Chile and Turkey. These cages used a UR30 woven copper mesh of $40 \mathrm{~mm}$ for final grow out of larger fish. The woven net is collapsible on land and is flexible in the water (http://www.ecosea.cl/). The mesh size is only available in large sizes and not suitable for studies with juvenile fish. The cages used in the New Hampshire field trial were small $\left(0.78 \mathrm{~m}^{3}\right)$ and in close proximity for replicate purposes and may not illustrate commercial significance. Setting of the experiment under a pier and with a new aquaculture species (cod) may not have been the best scenario for this study. Bacterial infection played a major part in the survival of the cod juveniles despite their continued growth. Future studies are warranted to reveal benefits and drawbacks of copper netting in aquaculture.

\section{Acknowledgements}

Special thanks to Luvata and Riverdale Mills who generously contributed the Seawire, and Jeff Beaton and Larry Walsh for expediting shipment of the material. Thanks also to Robert Love for his help in the design and construction of the culture system and to Great Bay Aquaculture for providing the juvenile cod. Lastly, I would like to acknowledge the International Copper Association, Hal Stillman and Robert Dwyer for their financial and technical support for the study.

\section{References}

1. Bakus G, Targett N, Schulte B (1986) Chemical ecology of marine organisms: an overview. J Chem Ecol12: 951-987.
2. Braithwaite RA, McEvoy LA (2005) Marine bio-fouling on fish farms and its remediation. Adv Mar Biol 47: 215-252.

3. de Nys R, Guenther J (2009) The impact and control of biofouling in marine finfish aquaculture. In: Advances in Marine Antifouling Coatings and Technologies. Woodhead Publishing, Cambridge, UK, 177-221.

4. Fredriksson D, Palcynski M, Swift M, Irish J (2003) Fluid dynamic drag of a central spar fish cage. In: Bridger C, Costa-Pierce B, (Eds.), Open Ocean Aquaculture. From Research to Commercial Reality. The World Aquaculture Society, Baton Rouge, Louisiana, 151-168.

5. Lader P, Dempster T, Fredheim A, Jensen O (2008) Current induced net deformations in full-scale cages for Atlantic salmon (Salmo salar). Aquac Eng 38 52-65.

6. Swift M, Fredriksson D, Unrein A, Fullerton B, Patursson O, et al. (2006) Drag force acting on bio-fouled net panels. Aquac Eng 35: 292-299.

7. Greene J, Grizzle R (2007) Successional development of fouling communities on open ocean aquaculture fish cages in the western Gulf of Maine, USA Aquaculture 262: 289-301.

8. Hodson S, Lewis T, Burke C (1997) Biofouling of fish-cage netting: efficacy and problems of in situ cleaning. Aquaculture 152: 77-90

9. Braithwaite R, Carrascosa CM, McEvoy L (2007) Biofouling of salmon cage netting and the efficacy of a typical copper-based antifoulant. Aquaculture 262 219-226.

10. Solberg C, Saethreb L, Julshamn K (2002) The effect of copper-treated net pens on farmed salmon (Salmo salar) and other marine organisms and sediments. Marine Pollution Bulletin 45: 126-132.

11. Dean R, Shimmield T, Black K (2007) Copper, zinc and cadmium in marine cage fish farm sediments: An extensive survey. Environmental Pollution 145 84-95.

12. Brooks M, Mahnken C (2003) Interactions of Atlantic salmon in the Pacific Northwest environment III. Accumulation of zinc and copper. Fisheries Research 62:295-305.

13. Brooks K, (2000) Determination of copper loss rates from Flexgard XI treated nets in marine environments and evaluation of the resulting environmental risks. British Columbia Ministry of Environment and the Canadian Department of Fisheries and Oceans, British Columbia.

14. Voulvoulis N, Scrimshaw M, Lester J (1999) Alternative antifouling biocides Applied Organometallic Chemistry 13: 135-143.

15. Chambers M, DeCew J, Celikkol B, Yigit M, Cremer M (2011) Small-Scale submersible fish cages suitable for developing economies. Global Aquaculture Advocate. 14:30-32.

16. Chester R (1990) Marine Geochemistry. Unwin Hyman, London, 698

17. Lie O, Julshamn K, Lied E, Lambertsen G (1989) Growth and feed conversion in cod (Gadus morhua) on different feeds, retention of some trace elements in the liver. Fisk Dir Skr Ser Ernaering 2: 235-244.

18. Noga E (1996) Fish Disease: Diagnosis and Treatment. lowa State University Press, Ames, lowa.

19. Van Duijn C (1973) Disease of Fishes. (3rdedn), Springfield III., Published by Charles C. Thomas.

20. Tookwinas S (1989) Larviculture of Seabass (Lates calcarifer) and groupe (Epinephelus malabaricus) in Thailand: advances in tropical aquaculture, Tahiti Aquacop IFREMER Actes de Colloque 9: 645-659.

21. Thoney D (1990) The effects of trichlorfon, praziquantel and copper sulphate on various stages of the monogenean Benedeniella posterocolpa, a skin parasite of the cownose ray, Rhinoptera bonasus. J Fish Dis 13: 385-389.

22. Cardeilhac PT, Whitaker BR (1988) Tropical fish medicine. Copper treatments. Uses and precautions. Vet Clin North Am Small Anim Pract 18: 435-448.

23. Chambers M, Howell W (2006) Preliminary information on cod and haddock production in submerged net pens off the coast of New Hampshire, USA. ICES Journal of Marine Science 63: 385-392.

24. Chambers M, Langan R, Howell W, Celikkol B, Watson W, et al (2007) Recent developments at the University of New Hampshire Open Ocean Aquaculture site. Bull. Aquaculture Association Canada 105-3. 
Citation: Chambers M, Bunker J, Watson III W, Howell WH (2012) Comparative Growth and Survival of Juvenile Atlantic Cod (Gadus morhua) Cultured in Copper and Nylon Net Pens. J Aquacult Res Dev 3:137 doi:10.4172/2155-9546.1000137

Page 5 of 5

25. Rillahan C, Chambers M, Watson W, Howell W (2011) The behavior of cod (Gadus morhua) in an offshore aquaculture net pen. Aquaculture 310: 361-368.

26. Rillahan C, Chambers M, Watson W, Howell W (2009) A self-contained system for observing and quantifying the behavior of Atlantic cod, Gadus morhua, in an offshore aquaculture net pen. Aquaculture 293: 49-56.

27. Moe H, Dempster T, Magne Sunde L, Winther U, Fredheim A (2007) Technological solutions and operational measures to prevent escapes of Atlantic cod (Gadus morhua) from sea cages. Aquaculture Research 38: 91-99.
28. Harris $L$ (1986) Size-selective predation in a sea anemone, nudibranch and fish food chain. The Veliger 29: 38-47.

29. Harris L, Irons K (1982) Substrate angle and predation as determinates in fouling community succession. In: Cairns, J. Jr. Artificial Substrates. Ann Arbor Science/Ann Arbor Science Publishers Ann Arbor, Michigan 131-174.

30. Lovely E (1995) Coexistence of hydroid predators and persistence of prey, Tubularia larynx and Tubularia indivisa (Hydrozoa: Tubulariidae), in shallow fouling communities. M.S. Thesis, University of New Hampshire. 